Bangladesh J. Sci. Ind. Res. 42(4), 425-434, 2007

\title{
Comparative Studies of Pulping of Jute Fiber, Jute Cutting and Jute Caddis
}

\author{
M. Sarwar Jahan, ${ }^{a}$ A. Al-Maruf and M. A. Quaiyyum ${ }^{b}$ \\ ${ }^{a}$ Pulp and Paper Research Division, BCSIR Laboratories, Dhaka, Dhaka-1205 \\ and ${ }^{b}$ Department of Applied Chemistry and Technology, \\ University of Dhaka, Dhaka-1000, Bangladesh
}

\begin{abstract}
Comparative studies of retted jute fiber, jute cuttings and jute caddis were carried out in producing dissolving and paper grade pulp. Fiber length of jute fiber was longer than jute cutting and caddis. Klason lignin content was lower and a-cellulose content higher in jute fiber than cuttings and caddis. Extractives content in caddis was higher than jute fiber and cuttings. Pulping of these raw materials was done in sodaanthraquinone process. Higher pulp yield and lower kappa number was observed in jute fiber than that of jute cuttings and caddis. Jute fiber pulp showed better papermaking properties than jute cuttings and caddis. The tear index of these raw materials was similar to softwood. The bleachability of jute fiber pulp was also better than that of cuttings and caddis. These three raw materials were also evaluated in producing dissolving pulp by prehydrolysed kraft process. Pulp yield and bleachability was higher and kappa number lower for jute fiber than jute cuttings and caddis, but $\alpha$-cellulose, $\mathrm{S}_{10}$ and $\mathrm{S}_{18}$ values and viscosity were almost similar in these three raw materials.
\end{abstract}

Keywords: Jute fiber, Jute cuttings, Jute caddis, Paper grade pulp, Dissolving pulp

\section{Introduction}

Today, the vast majority of paper pulp and other pulp products (viscose, cellulose derivatives, etc.) are obtained from wood. Despite a considerable increase of recycled fiber, the demand for virgin pulp grows continuously. The forest can no longer meet these needs. The use of cellulose fiber from annual plant is thus inevitable. Nonwood fiber is an important source for papermaking in many developing countries. Most papermakers and many consumers already are concerned for the environment and they campaign vociferously against the use of primary wood fibers in papermaking. It should also be kept in mind that fibers harvested annually have a high biomass production potential. Some 
nonwood plants even give more pulp per hectare per year than wood. In Bangladesh main source of raw materials for pulp and paper industry were gamar, gewa wood, bamboo, bagasse etc. The conventional forest resources in the country are decreasing day by day. Due to the inadequate supply of these raw materials, Khulna newsprint Mills and North Bengal Paper Mills have already been shut down. Karnaphuli Paper Mills is facing difficulties in collecting bamboo and gamar, which is the only running pulp mill in Bangladesh. Therefore, we have to find out alternative sources of fibrous raw materials.

Jute has a long historical role in the socioeconomic development of Bangladesh. Once it was known as "Golden fiber of Bangladesh". The export of jute and related products accounts for a significant portion of total export. In addition, it provides considerable employment opportunities to the country's work force. Traditionally jute was used in backing, sacking, gunny bag, hasein, etc. In recent years, jute has faced hard competition from synthetics. Therefore, traditional uses of jute have declined. As a result, its demand in local and overseas markets has declined. Therefore, diversified usage is needed to regain the lost glory of jute. The chemical and morphological characteristics of jute favor it as pulping raw material (Nahar 1987 and Jahan et al. 2007). Therefore, many studies have been done on the pulping of jute in home and abroad (Akhtaruzzaman and Shafi 1995, Jahan
2001, Jahan et al. 2005 and Roy et al. 1998). But the price of jute fiber cannot compete with wood. Bottom part of jute, removed in jute mills that is call jute cuttings. About 15 $\%$ jute cuttings and $3 \%$ caddis are produced in processing of jute fiber. Bangladesh produced 810,000 MT of jute fiber in 20042005 (Anon 2007). So about 1, 20,000 MT jute cuttings and 24, 300 MT caddis remained left over in jute mills. These may be used as pulping raw materials. In this investigation, comparative studies of jute fiber, jute cuttings and jute caddis were carried out in respect to chemical and morphological properties, and pulpability and bleachability. Pulping was done by sodaanthraquinone (AQ) process for paper grade pulp and prehydrolysis-kraft process for dissolving pulp.

\section{Materials and Methods}

\section{Materials}

Jute fiber, jute cuttings and caddis were collected from Jute Mill in Narayangong. Jute fiber was very clean and free from scaling. These were chopped to $2-3 \mathrm{~cm}$ in length, and ground (40/60 mesh) in a Wiley mill for chemical analysis.

For the measurements of fiber length, the sample was macerated in a solution containing 1:1 $\mathrm{HNO}_{3}$ and $\mathrm{KClO}_{3}$. A drop of macerated sample was taken on a slide and fiber length was measured under a profile projector (Nikon V-12, Japan). 


\section{Chemical analysis}

The extractives (T204 om88), Klason lignin (T211 om 83), and pentosan (T223 cm-84) were determined in accordance with Tappi Test Methods. Holocellulose was determined by treating extractive free wood meal with $\mathrm{NaClO}_{2}$ solution. The $\mathrm{pH}$ of the solution was maintained at 4 by adding $\mathrm{CH}_{3} \mathrm{COOH}-$ $\mathrm{CH}_{3} \mathrm{COONa}$ buffer.

\section{Pulping}

Soda-AQ pulping was done in a 5 l capacity thermostatically controlled electrically heated rotary digester. The active alkali was varied from $16-20 \%$ as $\mathrm{NaOH}$ on oven dried (o.d.) sample in the liquor ratio of 1:5. AQ was $0.1 \%$ o.d. raw material. The cooking was continued for $60 \mathrm{~min}$ at the maximum temperature $\left(170{ }^{\circ} \mathrm{C}\right)$. At the end of pulping, pressure was relieved to atmospheric pressure, pulp was taken out from the digester, disintegrated and washed by continuous flow of water. Pulp yield was determined as dry matter obtained on the basis of $\mathrm{o}$. d. raw material. Kappa number was determined in accordance with T $236 \mathrm{~cm}-85$.

All pulps were beaten in a PFI mill to 4000 revolution and handsheets of about $60 \mathrm{~g} / \mathrm{m}^{2}$ were made in a Rapid Kothen Sheet Making Machine according to German Standard Methods DIN 106. The physical properties of handsheets were determined by the method T 220 sp-96.

\section{Dissolving pulp}

Prehydrolysis: The prehydrolysis was carried out in an electrically heated stainless steel digester of $5 \mathrm{l}$ capacity, rotating at 1 rpm. The prehydrolysis was done with water at $150^{\circ} \mathrm{C}$ for $60 \mathrm{~min}$. The jute to liquor ratio was 1: 6 . The time required to raise max temperature was $40 \mathrm{~min}$. After prehydrolysis, jute fiber, cuttings and caddis were washed with water, squeezed and kept for pulping.

Pulping: The same digester was used for producing dissolving pulp. Jute fiber, cuttings and caddis were cooked in $18 \%$ active alkali as $\mathrm{Na}_{2} \mathrm{O}$ and $25 \%$ sulphidity for $60 \mathrm{~min}$ at $170{ }^{\circ} \mathrm{C}$. The liquor ratio was maintained at 5 . Pulp yield was determined on the basis of oven-dried raw material. Kappa number was determined as noted previously.

\section{Bleaching}

The pulp obtained from jute fiber, cutting and caddis was bleached by $\mathrm{DoED}_{1}$ bleaching sequences. The kappa factor was 0.22 in $\mathrm{DoED}_{1}$ bleaching. The temperature was $70{ }^{\circ} \mathrm{C}$ in Do stage for $60 \mathrm{~min}$. The $\mathrm{pH}$ was adjusted to 2.5 by adding dilute $\mathrm{H}_{2} \mathrm{SO}_{4}$. In alkaline extraction stage, temperature was $70{ }^{\circ} \mathrm{C}$ for 60 min and $\mathrm{NaOH}$ was $2 \%$. In the final $\mathrm{D}_{1}$ stage, $\mathrm{pH}$ was adjusted to 4 by adding dilute $\mathrm{H}_{2} \mathrm{SO}_{4}$. The strength properties of bleached pulps were determined according to Tappi Test Methods T 220 sp-96. 


\section{Evaluation of dissolving pulp}

Pulp tests were performed according to the Standard Methods of the Technical Association of the Pulp and Paper Industry (TAPPI, Atlanta, GA): kappa number (T 236 cm-85); brightness (T 452 om-92); viscosity (T 230 om-89); a-cellulose (T 203 om-88); and alkali solubility S10 and S18 (T 235 cm85). All pulp properties were analyzed in duplicate.

\section{Evaluation of papermaking properties}

Both bleached and unbleached jute fiber, cutting and caddis pulpsheets were tested for tensile (T 494 om-96), burst (T 403 om-97), tear strength ( $\mathrm{T} 414$ om-98) folding endurance ( $T 511$ om 96) and brightness (T525 om 92) according to TAPPI Standard Test Methods.

\section{Results and Discussion}

\section{Chemical properties}

Table I shows the comparative chemical composition of jute fiber, jute cuttings and jute caddis. The klason lignin in jute fiber was $12.7 \%$ which was $1.3 \%$ lower than jute cuttings. This difference may be attributed by the presence of unretted scale encrusted in jute cutting, which is obtained from the bottom part of jute. Lignin content in these raw materials was lower than wood (Fengel and Wegener 1984). The lower lignin indicates easier pulping of these raw materials. The a-cellulose content in jute fiber was higher and jute caddis lower than jute cutting. This can be explained by impurities and foreign materials of jute caddis. The range of a-cellulose content in these raw materials was 59-63 \%, which are higher than wood (Fengel et al. 1984). There was no significant difference in pentosan content in these three raw materials. The pentosan content varies from 13.5-14.1 \%. The dichloromethane (DCM) extractive in jute caddis was the highest among these three raw materials. Jute caddis is a left over of jute mills. Jute mills use oil for the softening jute. So caddis obtained after processes in the mills, obviously is higher in extractive than jute fiber and cuttings. Extractive in jute fiber was the lowest because it is obtained after retting and before any chemical treatment.

Table I. Chemical characteristics of jute fiber, cutting and caddis

\begin{tabular}{l|c|c|c}
\hline & Jute fiber & Jute cutting & Jute caddis \\
\hline Klason lignin, \% & 12.7 & 14.0 & 14.7 \\
Holocellulose, \% & 87.6 & 87.9 & 87.7 \\
$\alpha$-cellulose, \% & 63.1 & 60.0 & 58.6 \\
Pentosan, \% & 13.5 & 14.1 & 14.0 \\
Extractives (DCM), \% & 0.25 & 0.43 & 3.86 \\
\hline
\end{tabular}

DCM- Dichloromethane 


\section{Fiber length}

The fiber length of jute fiber, jute cutting and jute cadis was determined and is shown in Fig. 1. It is clear from figure that jute fiber was the longest $(2.54 \mathrm{~mm})$ and jute caddis was the shortest $(2.11 \mathrm{~mm})$ in fiber length. Caddis is result from shorter fiber of jute during processing. Fiber length of jute cuttings (2.14) was not significantly different from jute caddis. Shafi et al. (1993) observed that fiber length of jute was longest at the height of $75 \mathrm{~cm}$ from the bottom of jute and shortest at the bottom of jute. Jute cuttings usually obtained from the bottom part of jute. So the findings in this investigation are in agreement with the literature. Consequently, the papermaking properties of the pulp obtained from jute fiber, cutting and caddis are expected to vary. The fiber length of these raw materials was longer than tropical hardwood (Hale 1959).

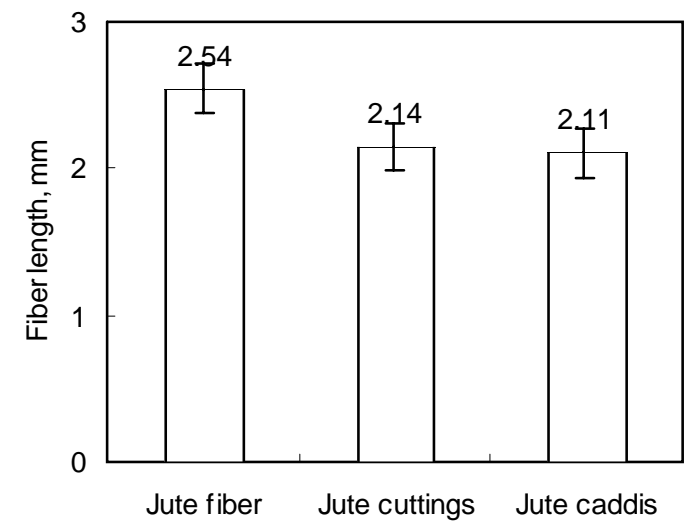

Fig. 1. Fiber length of jute fiber, jute cuttings and caddis

\section{Pulping}

Table II shows pulping results of jute fiber, jute cutting and jute caddies. It is observed that increasing alkali charge from 16 to $20 \%$ decreased pulp yield from 69.1 to $66.2 \%$ with jute fiber, 60.2 to $59.2 \%$ with jute cutting and 56.9 to $55.2 \%$ with caddis. This increase of alkali charge drops kappa number by 0.8, 1.8 and 2.6 units in pulp from jute fiber, jute cuttings and caddis. So $16 \%$ alkali charge is enough for jute fiber, jute cutting and jute caddies cooking for paper grade pulp. Jute fiber showed the highest pulp yield and lowest kappa number followed by jute cutting and caddies. This may be explained by higher impurities and foreign material in caddis and cuttings, which are dissolved during pulping and also higher acellulose in jute fiber (Table I). Pulp yield and kappa number were better than that of hardwoods (Parthasarathy et al. 1995). Easier pulping of these raw materials is due to lower lignin content (Table I) and higher syringyl to guaiacyl ratio (Islam and Sarkanen 1993). It is clearly seen from Fig. 2 that selectivity of pulping in jute fiber was the best followed by cuttings among these raw materials under employed cooking condition. At kappa number 10, jute fiber produced 10 per point higher pulp yield than caddis.

Pulp obtained from jute fiber, cuttings and caddis were beaten in a PFI mill for 4000 revolutions, and handsheets were prepared 
Table II. Pulp properties of jute fiber, cutting and caddis

\begin{tabular}{ll|c|c|c|c|c|c|c|c|c}
\hline & & \multicolumn{3}{|c|}{ Jute fiber } & \multicolumn{3}{c|}{ Jute cutting } & \multicolumn{3}{c}{ Jute caddies } \\
\hline Active alkali, \% as & $\mathrm{NaOH}$ & 16 & 18 & 20 & 16 & 18 & 20 & 16 & 18 & 20 \\
\hline Pulp yield, \% & & 69.1 & 67.9 & 66.2 & 60.2 & 59.7 & 59.2 & 56.9 & 56.2 & 55.8 \\
\hline Kappa number & & 11.0 & 10.4 & 10.2 & 13.9 & 12.5 & 12.1 & 13.2 & 11.3 & 10.6 \\
\hline OSR & Unbleached & 45 & 44 & 46 & 43 & 44 & 44 & 50 & 51 & 52 \\
& Bleached & 46 & 45 & 45 & 44 & 44 & 45 & 52 & 50 & 52 \\
\hline Tear index & Unbleached & 28.3 & 24.9 & 24.9 & 20.1 & 20.5 & 21.2 & 19.9 & 20.0 & 20.8 \\
mN.m ${ }^{2} / g$ & Bleached & 28.1 & 24.1 & 24.0 & 20.9 & 19.3 & 18.7 & 18.1 & 18.1 & 19.1 \\
\hline Burst index & Unbleached & 5.1 & 5.8 & 5.9 & 4.9 & 5.2 & 5.3 & 5.5 & 5.4 & 5.5 \\
kPa.m ${ }^{2} / g$ & Bleached & 5.0 & 5.2 & 5.3 & 5.0 & 4.9 & 4.9 & 5.4 & 5.0 & 4.7 \\
\hline Tensile index, & Unbleached & 42.7 & 48.0 & 47.8 & 40.9 & 42.4 & 41.0 & 42.1 & 44.9 & 40.6 \\
mN.m/g & Bleached & 40.3 & 45.6 & 45.4 & 35.3 & 35.9 & 35.8 & 40.2 & 44.2 & 37.5 \\
\hline Density, kg/m ${ }^{3}$ & Unbleached & 484.6 & 484.5 & 484.3 & 478.5 & 482.6 & 485.9 & 457.5 & 470.8 & 484.6 \\
& Bleached & 410.0 & 400.9 & 412.8 & 435.0 & 437.0 & 418.9 & 450.0 & 408.1 & 412.6 \\
\hline Folding & Unbleached & 5535 & 1820 & 1453 & 957 & 498 & 387 & 1274 & 1139 & 863 \\
endurance & Bleached & 2204 & 828 & 742 & 270 & 218 & 193 & 467 & 289 & 266 \\
\hline Brightness, \% & Unbleached & 37.2 & 38.1 & 39.4 & 34.2 & 35.4 & 36.1 & 36.1 & 36.2 & 3.7 .1 \\
& Bleached & 81.6 & 84.6 & 84.6 & 82.3 & 84.3 & 84.8 & 79.7 & 81.2 & 81.5 \\
\hline
\end{tabular}

for physical properties. The ${ }^{0} \mathrm{SR}$ value of caddis pulp increased to 50-52, while jute fiber and cutting pulp to 43-46 after 4000 PFI revolution. This easier beating of caddis pulp can be explained by loosening of fiber matrix during combing of jute in jute mill, where caddis is produced. The tear index of jute fiber pulp decreased and tensile index increased with increasing alkali charge. Jute fiber pulp showed the best tensile-tear ratio. The highest tear index $\left(28.3 \mathrm{mN} \cdot \mathrm{m}^{2} / \mathrm{g}\right)$ was obtained at tensile index of 42.7, where tear index of jute cutting was $20.5 \mathrm{mN} . \mathrm{m} 2 / \mathrm{g}$ and caddis $18.1 \mathrm{mN} . \mathrm{m}^{2} / \mathrm{g}$ (Fig. 3). Tear index of these raw materials was much higher than hardwood (Watson et al. 2003). The higher fiber length of jute fiber may be the reason of higher tear index of jute fiber (Fig.1). The burst index of jute fiber and cutting pulp was almost similar (5-6 kPa.m²/g) as shown in Table II. Burst index of caddis pulp was inferior. The density of these pulps was almost similar which was within the range of 460$485 \mathrm{~kg} / \mathrm{m}^{2}$. Double fold number jute fiber 


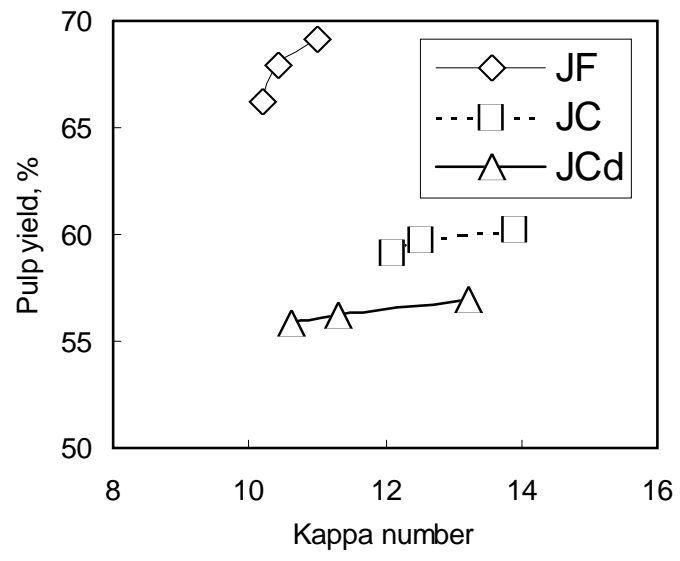

Fig. 2. Pulping selectivity of jute fiber, jute cuttings and caddis (JF- jute fiber, JCjute caddis, JCd- jute caddis)

pulp was very high and it was decreased from 5500 to 1400 with increasing alkali charge from 16 to $20 \%$. Double fold number of jute fiber was $82 \%$ higher jute cutting and $77 \%$ than caddis.

\section{Bleaching}

These pulps were bleached by DoED $_{1}$ bleaching sequence. The bleachability of pulp improved with the increase of alkali charge (Table II). This result is in good agreement with previous findings showing that a high residual alkali at the end of cook is beneficial to bleachability (Colodette et al. 2002). Similar results were also observed in soda-AQ pulping (Olm et al. 2001). The bleachability of jute fiber pulp was better than that of cutting and caddis. Jute fiber pulp consumed $2.75 \mathrm{~g} \mathrm{ClO}_{2} / 100$ g pulp to produce brightness of $84.6 \%$, while jute cut

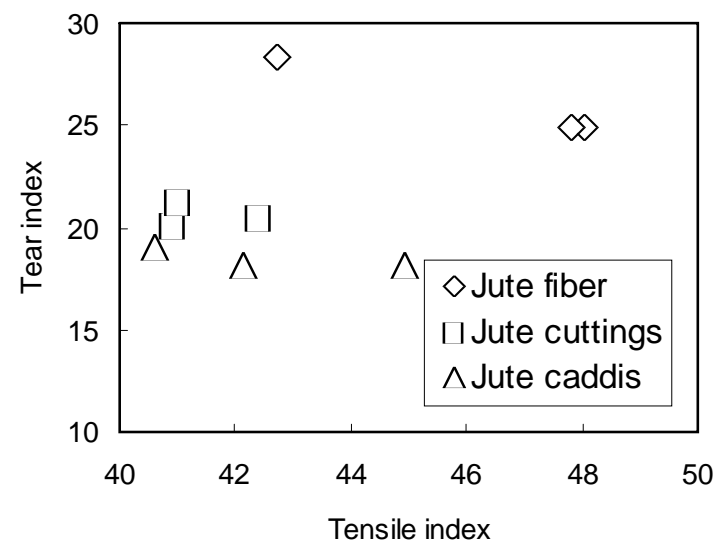

Fig. 3. Tensile-tear relationship of jute fiber, jute cutting and caddis pulp

ting consumed $3.3 \mathrm{~g} \mathrm{ClO}_{2} / 100 \mathrm{~g}$ pulp (Fig 4). The caddis pulp required $2.86 \mathrm{~g} \mathrm{ClO}_{2} /$ $100 \mathrm{~g}$ pulp to produce $81.5 \%$ brightness. The physical properties of jute fiber pulp retained its superiority even after bleaching. The best tear index of bleached jute fiber pulp was $28.1 \mathrm{mN} \cdot \mathrm{m}^{2} / \mathrm{g}$, which was $26 \%$ higher than cutting and $32 \%$ than caddis. The double fold number was tremendously detoriated on bleaching.

\section{Dissolving pulp}

Prehydrolysed kraft pulping was carried out in producing dissolving pulp from jute fiber, jute cuttings and jute caddis under identical conditions. Pulp yield of jute fiber was $59.9 \%$, which was $10 \%$ higher than jute cutting and caddis (Fig. 4). This difference was due to impurities in jute cuttings (scale) and caddis (batch oil). The kappa number of jute 


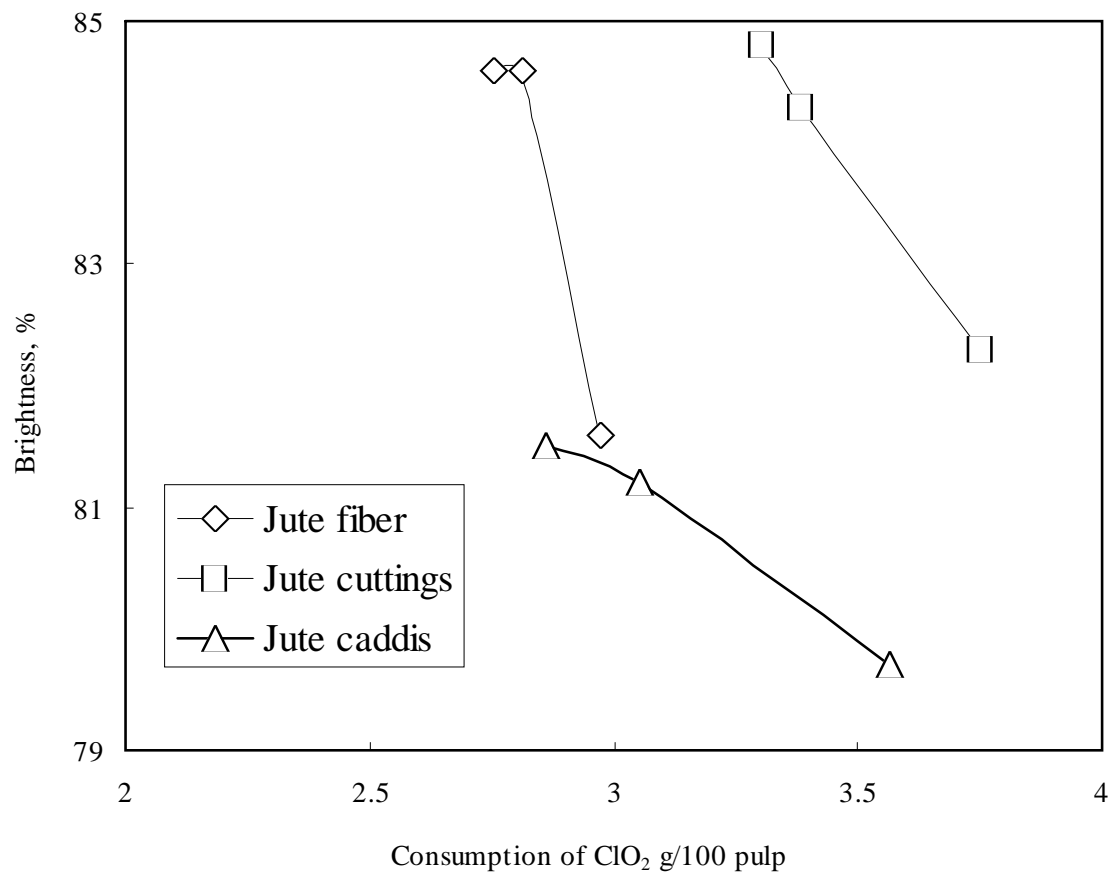

Fig. 4. Bleachability of jute fiber, jute cuttings and caddis pulp

fiber, cuttings and caddis was 10.9, 11.2 and 12.5, respectively as shown in Fig. 5. The $\alpha$-cellulose content in jute fiber pulp did not differ significantly from that in cuttings and caddis pulps. It was 91.0-91.8 \% (Table III). The main target parameter in dissolving pulp production besides purity ( $\alpha$-cellulose) is viscosity as a measure of the degree of polymerization of the cellulose. In dissolving pulp production the viscosity must always be considered in relation to purity, i.e., cellulose content of the pulp. The viscosity of jute cutting and caddis pulp was almost similar (4.5$4.6 \mathrm{mPa} . \mathrm{s})$, but jute fiber pulp was slightly better (6.3 mPa.s) as shown in Table III.
The solubility in $10 \%$ alkali $\left(\mathrm{S}_{10}\right)$ in jute fiber and cuttings pulp was similar (10.3\%) and in jute caddis was $11.4 \%$. The higher $\mathrm{S}_{10}$ value of caddis pulp indicated that both cellulose and hemicellulose were degraded in the cooking conditions used. Therefore, the hemicellulose content in pulp was also higher $\left(\mathrm{S}_{18}=7.3\right)$ in caddis. $\mathrm{S}_{10}-\mathrm{S}_{18}$ values indicate the content of degraded cellulose with a degree of polymerization between approximately 50 and 150 (Hinck et al 1985). $\mathrm{S}_{10}$ $\mathrm{S}_{18}$ value in jute fiber pulp was only $2.3 \%$, while it was $3.4 \%$ in jute cutting and $4.1 \%$ in caddis. 


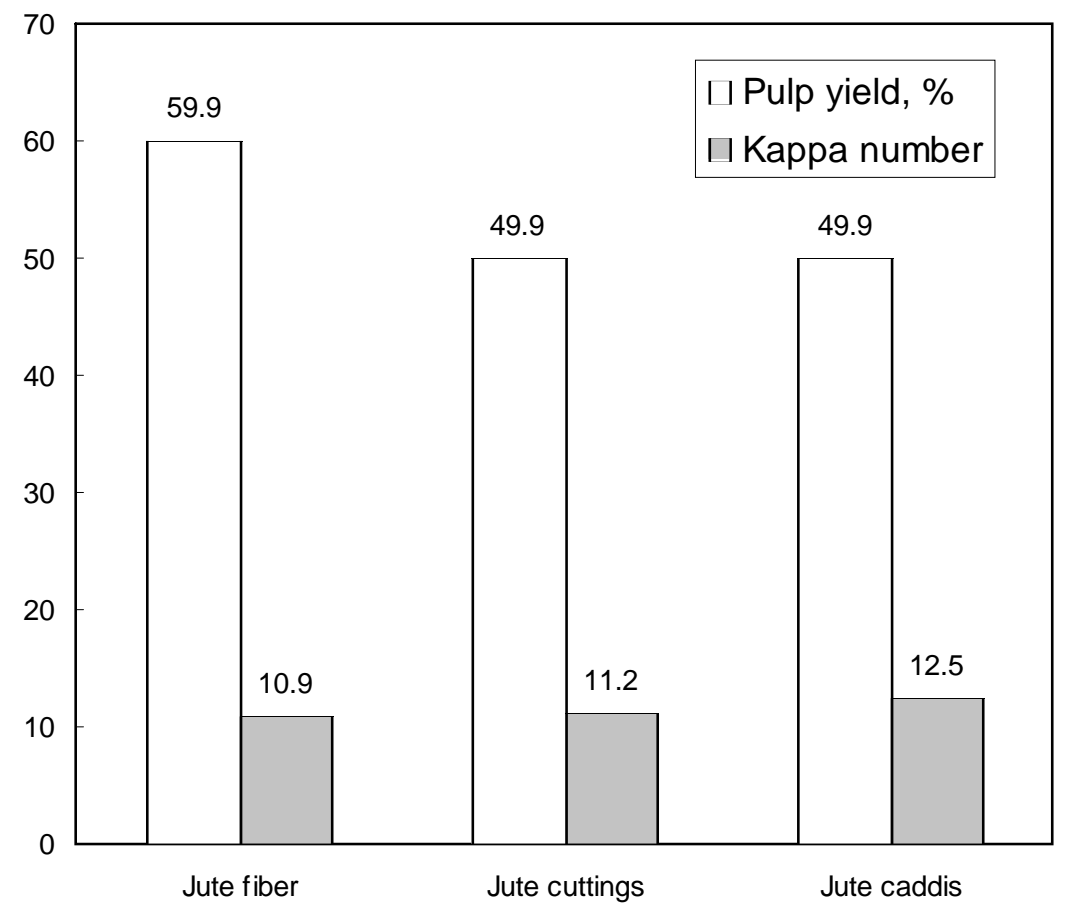

Fig. 5. Pulp yield and kappa number of jute fiber, jute cuttings and caddis in prehydrolysedkraft process

Table III. Properties of dissolving pulps from lignin than jute cutting and caddis. Fiber jute fiber, cutting and caddis

\begin{tabular}{l|c|c|c}
\hline & Jute fiber & Jute cutting & Jute caddis \\
\hline$\alpha$-cellulose, \% & 91.8 & 91.0 & 91.3 \\
$\mathrm{~S}_{10}, \%$ & 10.3 & 10.3 & 11.4 \\
$\mathrm{~S}_{18}, \%$ & 8.0 & 6.0 & 7.3 \\
$\mathrm{~S}_{10}-\mathrm{S}_{18}, \%$ & 2.3 & 3.4 & 4.1 \\
Viscosity, mPa.s & 6.3 & 4.6 & 4.5 \\
Brightness, \% & 83.4 & 80.9 & 77.9 \\
\hline
\end{tabular}
length of jute fiber is also longer.

\section{Conclusions}

The following conclusions are drawn from this investigation:

* Consequently pulp yield and kappa number of jute fiber are higher than cutting and caddis that are also better than hardwood.

* All these three raw materials have tear index similar to softwood and higher than hardwood. Jute fiber shows the best result among these raw materials.

* The bleachanility of these raw materials is very good; among this jute fiber shows better bleachanility than cutting and caddis.

* Jute fiber contains high a-cellulose and low 
* Dissolving can be produced from these raw materials with purity of above $91 \% \alpha$-cellulose. The properties of dissolving pulp are not significantly different from these raw materials.

\section{References}

Akhtaruzzamen, A.F.M. and Shafi M. (1993). Pulping of jute Tappi 78(2): 106.

Anon. 2007. www.jute.org

Colodette, J.; Gomide J.L.; Girard R., Jaaskelainen A. S. and Argyropoulos D. S., (2002) Influence of pulping conditions on eucalyptus kraft pulp yield, quality and bleachability Tappi. J, 1(1): 14-20.

Fengel, D. Wegener and G. Wood: Chemistry (1984) Ultrastructure, Reaction. Walta de Gruyter, Berlin, p56.

Hale, J.D.; (1959): Physical and anatomical characteristics of hardwoods. Tappi J. 42(8) 670-677.

Islam A. and Sarkanen K. V. (1993). The isolation and characterization of the lignin of jute (Corchorus capsularis). Holzforschung 47: 123-132.

Jahan, M.S. (2001). Evaluation of additives in soda pulping of jute. Tappi J. 84(8): 1-11.

Jahan, M.S., Nasima Chowdhury, D.A. and Islam M.K. (2005). Alkaline sulphite anthraquinone methanol (ASAM) Pulping of jute. IPPTA J. 17(3): 37-43.
Jahan, M.S. Kanna, G. H., Mun, S.P. and Chowdhury, D.A. N. (2007). Variations in Chemical Characteristics and Pulpability within Jute Plant (Chorcorus capsularis). Under communication.

Nahar N. (1987) Studies on carbohydrates in jute and pigeon pea Swedish University of Agriculture Sciences, Uppsala p. 42

Olm L, Hakansdotter L and Jonsson T, Recent (2001) Development in soda-AQ cooking. Das Papier 12: 41-45.

Parthasarathy, V. R. Smith, G. C. Glenn, Rudie, F. Detty, A.E. and Steffy, J.J. (1995). Application of anthraquinone in extending the delignification of kraft and polysulfide pulps Part 1: Pulping and bleaching of mixed hardwoods. Tappi J. 78(2): 113-125.

Roy T.K. Mohindru V.K. Behera N.C. Kulkarni A.G. and Prasad A. (1998). Jute for speciality pulp. Ippta J. 10(3): 81-86.

Shafi, M. Akhtaruzzamen, A.F. M. and Mian, A.J. (1993) Pulping of whole length jute by neutral sulphite anthraquinone (NS-AQ) process. Holzforschung. 47: 83-87.

Watson P. Hussein A. Sandy R. Gee W. and Hatton J. Drummond (2003) The kraft pulping of Candian red and sugar maple Tappi J. 6(2): 26-32.

Received : July, 11, 2007;

Accepted : August, 15, 2007 